\title{
The Significance of the Date Palm as a Decorative Motif in the Synagogues of Cairo, Egypt
}

\author{
Manal Mahmoud Abdelhamid* \\ Associate Professor, Tour Guidance Dep. Faculty of Tourism and Hotels, Alexandria University, Egypt \\ *Corresponding Author: Manal Mahmoud Abdelhamid, Associate Professor, Tour Guidance Dep. \\ Faculty of Tourism and Hotels, Alexandria University, Egypt
}

\begin{abstract}
Cairo is a beautiful city with a great ancient history where many nationalities with different religious beliefs and concepts lived peacefully and practiced their rituals freely. The Jews settled in Cairo for many years, worked in prominent professions and built many outstanding buildings like palaces, schools, stores and synagogues where the Jewish artist was keen on showing the Jewish symbols as a reference to the ancient Temple in Jerusalem. The date palm is extensively represented in the synagogues of Cairo in different positions like facades, doors, walls and in the sanctuary in different forms and sizes and alternating with other Jewish symbols like Star of David and Tablets of Law. The research adopted the descriptive methodology of these representations to clarify the religious significance of the date palm in Judaism.
\end{abstract}

Keywords: Date Palm, Motif, Synagogue, Cairo, Judaism, Bible, Symbol

\section{INTRODUCTION}

Cairo, the capital of Egypt, is a city of rich history where one can experience the variety of cultures that can be traced through the archaeological and architectural remnants. Through its great history, Cairo embraced many nationalities with different religious beliefs who lived together peacefully, building their own sanctuaries and practiced their rituals freely.

Jews settled in Fust at (old Cairo) since its foundation by the Arabs in 641 A.D. with the native Egyptian Christians and Arabs. During the tenth century, many Jewish immigrants came from Baylonia and Iraq to Fustat forming one of the oldest Jewish communities in the world. After the Fatimid conquest of Egypt in 969 A.D., the new town of Cairo was founded north of Fust at when the Jews immediately settled in two quarters in the northern and southern parts of the city, then they were removed by the caliph Al-Hakim, at the beginning of the eleventh century to a new location where they founded the Jewish quarter and built many synagogues.

The economic development of Egypt under the reign of Muhammed Ali (1805-48), attracted many Jews from the Mediterranean countries to come and settle in Cairo, worked in commerce and banking, built many buildings including synagogues, houses, stores and schools according to the European standards. In the beginning of the nineteenth century, there were about 29.000 Jews in Cairo including Karaite, Sephardic and Ashkenazi Jews. ${ }^{1}$

According to the 1947 population census of Egypt, there were about 41.860 Jews in Cairo, the rich of them moved from the ancient Jewish quarter to the newer districts like Zamalek, Heliopolis and Garden City. They were active in public affairs and appointed to the Legislative Assemblies and government institutions like Jacob Cattaui who became the khedive Ismaeal Pasha's private banker and the chief revenue officer of Egypt.

Due to the arrests of Cairo Jews in 1948-1949, the deportations in 1956-1957 and the damage of the Jewish stores, schools and houses, only 5,587 Jews remained in Cairo and in 1970, the number reduces to about 1.500 Jews to reach only 200 Jews at the beginning of the twenty first century. ${ }^{2}$

\footnotetext{
${ }^{1}$ Morabia A., "L'etoile et la Croissant", inJuifs D'Egypt, Images et Textes, edited by Cabasso, G.,Carasso E., and Cohen A., 1984, pp.27-28

${ }^{2}$ Miccoli, D.,Histories of the Jews of Egypt: An Imagined Burgeoisie", 1880s-1950s. Routledge, 2015,pp.4-10
}

International Journal of History and Cultural Studies (IJHCS) 
The most distinguished feature of the Jewish presence in Cairo is the magnificent synagogues where one can see the beautiful architecture, decorations and ceremonial objects and feel the glory of the Jewish Egyptian heritage.

\section{The ArChitecture OF THE Synagogue}

The word "Synagogue" comes from the Greek word means "an assembling together". The synagogue as a permanent institution was originated probably in the period of the Babylonian captivity, when the religious life was reorganized and had become necessary to have a place for congregational worship consisting of prayer and the reading of sections from the Bible, and thus led to the building of synagogues. ${ }^{3}$

This place of meeting was called "bet ha-keneset" since an assembly of the people for worship was termed a "keneset"; while the assembly described in Neh. ix.-x. was known in tradition as "keneset hagedolah" or the "great assembly, but the synagogue was called briefly "keneset", "kanishta" in Aramaic and $\sigma v v \alpha \gamma \omega \gamma \eta$ in Greek. ${ }^{4}$

The Synagogue, then, was the center of activities of each community, just as the Temple at Jerusalem had been the center for the entire people. Indeed, the Synagogue became for each scattered community a sanctuary in miniature in compensation for the loss of the Temple at Jerusalem. Therefore, no matter how details may vary in different countries, synagogual worship was the most important visible expression of Judaism, and it was the chief means of uniting the Jews scattered throughout the world.

The earliest actual place of worship of the Jews is known as the tabernacle which was a kind of movable tents, consisted of an open vestibule (Ulam), the Holy Place (Hekal) and an inner chamber called the Holy of Holies which was elevated above the level of the Temple proper. The enclosure around the tabernacle consisted of twenty-one columns upon the sides andeleven upon the front, erected like tent poles. White immovable hangings were fastened between these columns, except at the entrance on the eastern front where movable curtains of blue, purple and scarlet linen filled the open spaces. The Holy of Holies, square in plan, was separated from the larger ante-chamber by four gilded columns and it contained the Ark of the Covenant. An altar of incense and a large table for the twelve loaves of shew-bread were enshrined in the sanctuary besides the seven-armed candlestick and other ceremonial objects. ${ }^{5}$

These main features of the Temple are clearly presented in the synagogue, the main body of the synagogue recalls the porch (Ulam) which, in the Temple, was the space given over to the needs of the congregation, The Hekal, which was reserved for the priests and contained the seven-armed candlestick, the table for the shew-bread and the altar of incense, is now symbolized in the synagogue by the Bima and the holy of holies is designed for the Ark, always raised above the floor level and separated from the rest of the synagogue area, and connected by an aisle for processionals. As for the richly embroidered curtain (Parodet), itisusually hung before the door of the shrine. ${ }^{6}$

Most of the synagogues derived their main form from the Roman basilicas existed in all parts of the Empire and were the most convenient structures then existing for purposes of congregational worship, while some other synagogues follows either the "Greek cross" or the "two aisle" plans.

The basilica form quite suited the needs of religious services, and then became as a model for the synagogue, as it did later for the Christian church. The plan was uniform, consisting of a parallelogram, divided into three parts, longitudinally, by two rows of columns or pillars, with galleries over the two outside divisions.

However, no matter the design, the arrangements for the conduct of the services and rituals remained fixed, the Ark is placed against the short wall, elevated upon a platform and preceded by steps. The Almemar or reading desk, also elevated above the floor, stood in the center of the room facing the Ark, a wide furnished ample designated for the procession and ceremonials. The women were assigned to a separate section that was located either on the ground floor or in an upper floor. ${ }^{7}$

\footnotetext{
${ }^{3}$ Tachau, W.G. The Architecture of the Synagogue, Jewish Pub. Soc. of America, 1926, p.155; Jacobs J., BrunnerA. W., "SYNAGOGUE ARCHITECTURE", Jewish Encyclopedia.V.11, P.631

${ }^{4}$ Bacher W. , Dembitz L.N., "SYNAGOGUE”, Jewish Encyclopedia.V.11, P.619-

${ }^{5}$ Tachau, W.G. The Architecture of the Synagogue,p.168

${ }^{6}$ Tachau, W.G.The Architecture of the Synagogue,p.159

${ }^{7}$ Tachau, W.G.The Architecture of the Synagogue, p.171
} 


\section{The Date Palm}

The date palm is an evergreen tree that grows in tropical dry climate, it has a slender stem and many branches, when the fruit begins to grow it has a green color which gradually changes into yellow and red until it becomes quite dark.

The term for date palm is commonly mentioned in ancient languages; in the Aramaic, Ethiopic, and Hebrew, it is known as "tamar" (תמר) and "tamr" in Arabic. It was used for food, and from it a kind of honey was pressed, its leaves were used as a roof-covering, the stem used for building purposes and parts of the stalk were used to weave ropes.

The date palm was considered the national symbole of Israel which is mentioned in the Bible under the name "the city of the palm trees":"There is the Negeb (desert) and the Jordan Valley; and Jericho, the city of palm trees; and Zoar, the Lord told him."(Deuteronomy 34.3). ${ }^{8}$

Moreover, The prophetess Deborah dispensed judgment from under a palm tree: "And Deborah, a prophetess, the wife of Lapidoth, judged Israel at that time lived under the palm tree of Deborah between Ramah and Beth-El in Mount Ephraim; and the people of Israel came up to her for judgment" (Judg. 4:4-5).

The date palm was considered also the symbol of plentifulness, fertility and blessing:"Planed in the house of the Lord, they flourish in the forecourts of the God. Even in old age they bud forth afresh, they are full of sap and grow green" (Ps.92:12). The righteous man is also described as being flourished like the date palm: "The righteous shall flourish like the palm tree; he shall grow like a cedar in Lebanon (Ps. 92:13). ${ }^{9}$

Due to its beautiful tall graceful stem, the Arab poets considered the date palm tree a figure of their lady love, and the same imagery is also found amongst the Hebrews (Can.vii, 8-9) who used "Tamar", the Hebrew name of palm tree, to describe the beautiful woman: "King Davids son, Absalom, had a beautiful sister named Tamar." (Samuel 13.1) and "He, (Absalom), had three sons and one daughter, Tamar, who was a very beautiful girl." (Samuel 14.27). ${ }^{10}$

During the Sukkot festival, the Jews used to shake the palm branches and use long stout leaves to build temporary tents and shelters: "And you shall take on the first day the boughs of goodly trees, branches of palm trees, and the boughs of thick trees, and willows of the brook.............. and (build shelters with them and you shall rejoice before the Lord your God seven days" (Lev. xxiii. 40; Neh. viii. 15). ${ }^{11}$

Palm tree was often considered a symbol of the Jewish state, and is often mentioned in connexion with the architectural ornaments of Solomon's Temple as well as in the plan of Ezekiel's temple in the decoration of walls, doors, entrances and rooms (including the Holy of Holies):

"He carved the walls of the house all around about with carved engravings of Cherubim, palm trees, and open flowers in the inner and outer rooms". (Kings 1, vi, 29).

"The walls were decorated with carvings of cherubim, each with two faces and of palm trees alternating with cherubim."(Ezekiel 41.18).

"One face,....that of a man....looked toward the palm tree on one side, and the other face...that of a young lion....looked toward the palm tree on the other side: and so it was, all around the inner wall of the Temple" (Ezekiel 41.20).

"The doors leading into the nave were decorated with cherubim and palm trees, just as on the walls...There were recessed windows and carved palm trees on both sides of the entry hall, the hallways beside the Temple, and on the canopy at the entrance" (Ezekiel 41 25-26), "Figures of

${ }^{8}$ Frankel E.,Teutsch B.P.," Lulav", The Encyclopedia of Jewish Symbols, Oxford,1995, p.2016; Hirsch E.G., Levi G.B.,'PALM (Phœnix dactylifera)",Jewish Encyclopedia, V.9,PP.505-506

${ }^{9}$ Farbridge M.H.,Studies in Biblical and Semitic Symbolism, Trübner's Oriental Series, Routledge, 2000,p.39

${ }^{10}$ Farbridge M.H.,Studies in Biblical and Semitic Symbolism,p.40; Frankel E.,'Lulav", The Encyclopedia of Jewish Symbols, 1995,pp.100-101

${ }^{11}$ Kern-Ulmer R.,"The Sha'ar Ha-Shamayim Synagogue (Keniset Ismā'̄̄lìyah) in Cairo, Egypt",in Maven in Blue Jeans, A Festschrift in honor of Zev Garber, edited by Steven Leonard Jacobs, Purdue University Press, 2009, p.432 ; Frankel E.,"Four Species", The Encyclopedia of Jewish Symbols, 1995,p.59 
angels, palm trees, and open flowers were carved on all the walls of both rooms of the Temple and the floor of both rooms was overlaid with gold" (Kings 6.29). ${ }^{12}$

\section{The Date Palm Representations in the Synagogues of Cairo ${ }^{13}$}

Through the following examples, it is obvious that the date palm is used extensively in the synagogues of Cairo in different places with various forms and sizes as a reference to the ancient temple in Jerusalem.

\subsection{In the Sanctuary}

Most of the representations of the date palm can be found in the sanctuary, either sculptured in wood, stone or metal:

\subsubsection{The Sanctuary of Moussa Dari Synagogue ${ }^{14}$}

On both sides of the sanctuary, there are a double palm reeds sculptured in stone in the upper part of the wall. The date palm is also represented on the four panels of Ark door, sculptured in high relief in wood (PL.1a, b). ${ }^{15}$

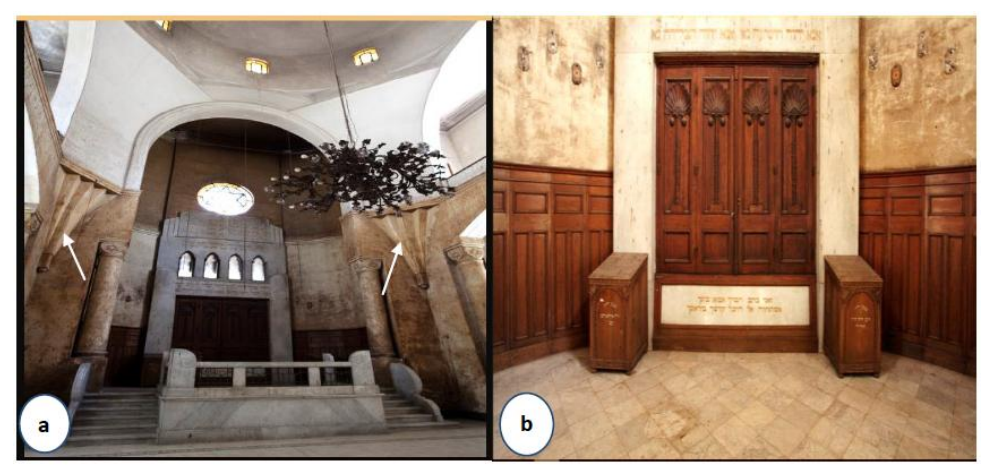

PL1. $a$-The Date Palm Motif on upper part of the Wall, b-On the Ark Door

\subsubsection{The Sanctuary of Haim Capousi Synagogue ${ }^{16}$}

The double- leaf door of the ark is decorated with two date palms and Tablets of Law, with Hebrew inscriptions engraved on the middle of the stem (PL.2).

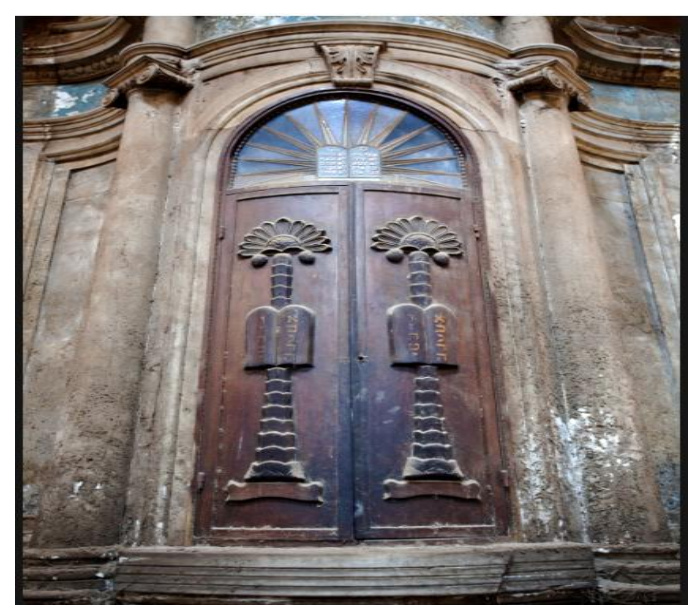

PL2. The Date Palm Motif on the Ark Door

\footnotetext{
${ }^{12}$ Farbridge M.H., Studies in Biblical and Semitic Symbolism, pp.40-41

${ }^{13}$ Most of the description of the date palm motif is done by the researcher

${ }^{14}$ Moussa Dari synagogue is located in Al Waili, it was completed in 1933 on a land donated by the widow of Sitatah Musafi, it is named after the famous Karaite poet Moshe (Moussa) Dari, https://diarna.org/exhibits/thesynagogues-of-cairo-and-alexandria-egypt-selected-sites

${ }^{15}$ Ark is the most important feature of the synagogue situated at the eastern end raised upon a suitable platform, reached by at least three steps, the Torah scrolls are stored in it, Jastrow M., Jr., McCurdy J.F., and others,"ARK OF NOAH", Jewish Encyclopedia, V.2,P.P.111

${ }^{16}$ Haim Capousi Synagogue is located in Haret El Yahud, dated back to 1631 and named after Rabbi Haim Capousi,https://diarna.org/exhibits/the-synagogues-of-cairo
} 


\subsubsection{The Sanctuary of Meir Enayim Synagogue ${ }^{17}$}

Two candelabras in the form of date palm placed on both sides of the Ark door and equipped with six lamps each (PL.3).

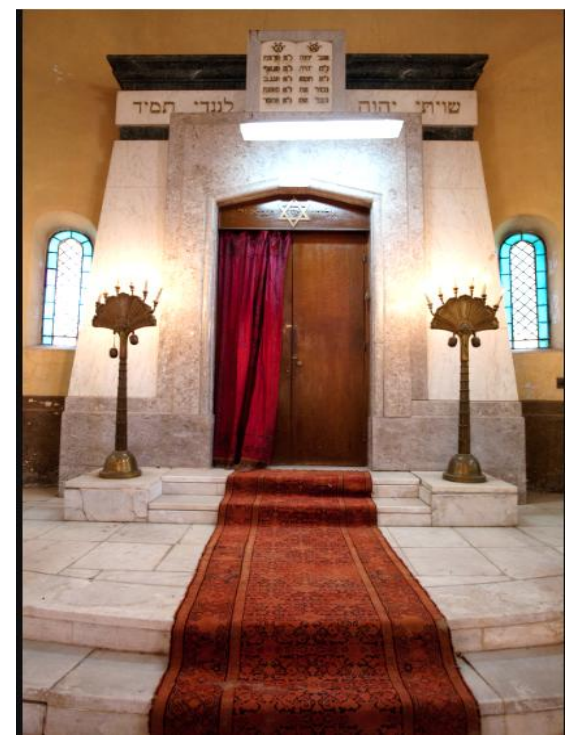

PL3. The Date Palm Candelabrason bothe Sides of the Ark Door

\subsubsection{The Sanctuary of Sha'ar Ha-Shamayim Synagogue ${ }^{18}$}

In Sha'ar Ha-Shamayim synagogue, the artist adopt the date palm as the main decorative motif for the whole building, it is represented on facades, inner walls, doors and in the sanctuary.

The Arkhas a large wooden carving of date palm trees on its right and left side and on each of the two sides of the sanctuary, there aretwo marble columns above them placed two large candelabras in the shape of palm trees equipped with six lamps each, exactily like those in Meir Enayim synagogue but smaller in size. The wooden door of the Arkis carved with the same date palm tree motif with detailed roots (PL.4 a,b,c). ${ }^{19}$

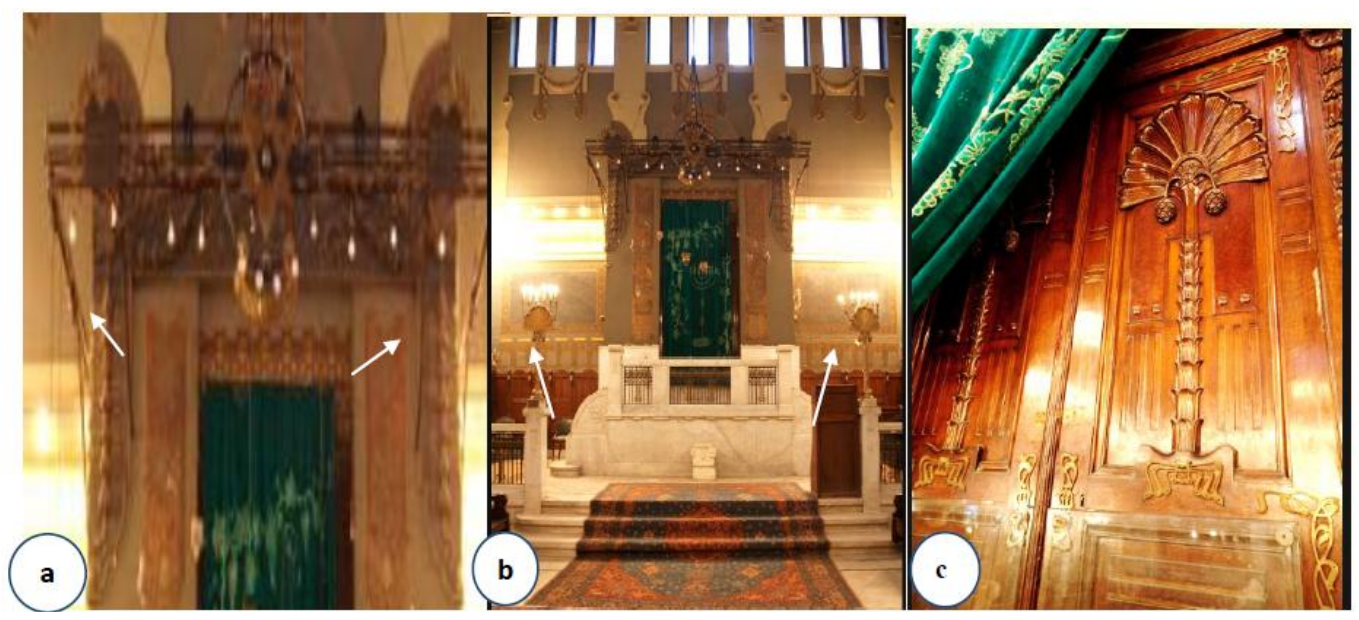

PL4. The Date Palm Motif in the Sanctuary of Sha'ar Ha-Shamayim Synagogue $a$-Wooden Carving, b-Two Candelabras, $c$-On the Ark Door

\footnotetext{
${ }^{17}$ Meir Enayim Synagogue is located in Maadi and dated back to 1934, https://diarna.org/exhibits/thesynagogues

${ }^{18}$ Sha'ar Ha-Shamayim Synagogue is commonly called Keniset Ismaealia,built in 1903 by the family of Mosseri Bey, partially designed by the Italian architectBranchi, Kern-Ulmer R.,The Sha'ar Ha-Shamayim Synagogue (Keniset Ismā 'ìlìyah) in Cairo, p.432

${ }^{19}$ Kern-Ulmer R.,The Sha'ar Ha-Shamayim Synagogue (Keniset Ismà'ìlīyah) in Cairo, p.436; https://diarna.org/exhibits/the-synagogues-of-cairo-and-alexandria-egypt-selected-sites; Taragan H.,The "Gate of Heaven"(Sha'ar Hashamayim) Synagogue in Cairo (1898-1905): On the Contextualization of Jewish Communal Architecture, Journal of Jewish Identities 2009, 2(1),PP.31-53
} 
In yhe sanctuary, ametal candelabrum with nine branches in the design of a palm tree stands in front of the dais on a small pedestal equipped with six lamps; the wooden pedestal itself is in scroll form and decorated with vegetal motifs. On the rear wall of the sanctuary the date palm motif is also engraved alternating with David Star and Tablets of Law $(\mathbf{P L . 5} \mathbf{a}, \mathbf{b}) .{ }^{20}$
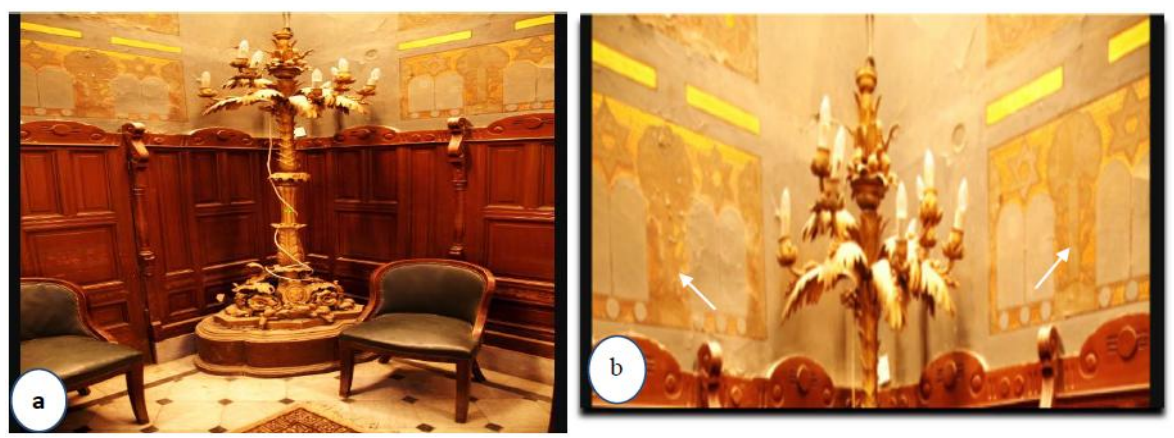

PL5. $a$-The Date Palm Candelabrum, $b$ - Date Palm Motif on the Rear Wall of the Sanctuary

\subsubsection{The Sanctuary of Maimoides Synagogue $e^{21}$}

A cylindrical Torah case made of wood and silver has a flat roof and base, the inner face is plain wood. The case is divided into two vertical halves, closed by a hook in the front and joined by two hinges at the back. It is covered with velvet, and decorated with silver friezes that frame the upper and lower borders and run along its openings. Four silver triangles mark the corners of each half cylinder. ${ }^{22}$

A large date palm with two clusters of dates is set in the center, topped by the Tablets of the Covenant ${ }^{23}$ inscribed with the Ten Commandments. A crown adorns the Tablets and inscribed "The crown of Torah", an oval-shaped wreath frames the tree, the coronet is formed by a running band of Stars of David alternating with lilies. ${ }^{24}$

The tree grows from vase, inscribed with a Hebrew dedicatory inscription, written in square, outlined characters:

"This Torah scroll and its case, together with the sacred objects adorning it, were dedicated to the Lord, by me - the servant of the Lord - Isaac Miragi, May the Lord sustain protect him. For the exaltation of the soul of my deceased wife who died young, Mrs. Simcha daughter of Moshe ben Tata, May he rest in heaven. She passed away on the second day of the month of Kislev, the year 5665 (10.11.1904).May her soul be bound in the bond of life, Amen"(PL.6). ${ }^{25}$

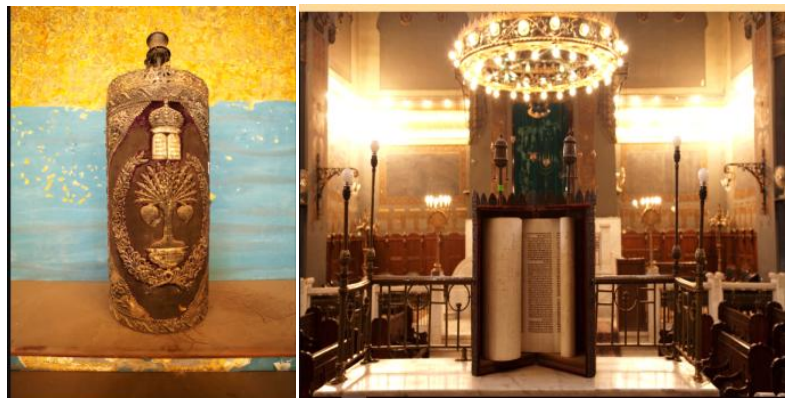

PL6. Left-The Cylindrical Torah Case with Palm Motif, Right-The Torah Scroll inside it

\footnotetext{
${ }^{20}$ Kern-Ulmer R.,The Sha'ar Ha-Shamayim Synagogue(Keniset Ismā'̄illiyah) in Cairo ,p.437; https://diarna.org/exhibits/the-synagogues-of-cairo-and-alexandria-egypt-selected-sites

${ }^{21}$ Maimoides Synagogue is located in Haret El Yahud, named after Rabbi Mosche ben Maimon who was one of the most famous physicians, after his death, he was buried in it, hence transferring the synagogue to a pilgrimage site for sick Jews and Muslims who searched for healing, https://diarna.org/exhibits/the-synagogues ${ }^{22}$ Center for Jewish Art, http://cja.huji.ac.il/wpc/browser.php? mode=alone \&id=22504

${ }^{23}$ They are two stone tablets, also known as Tablets of the Law, inscribed with the Ten Commandments when Moses ascended biblical Mount Sinai, Hirsch E.G.,"Tables of the Law", Jewish Encyclopedia, V.11,P.662

${ }^{24}$ Stars of David is also known as the Shield of David, cosnsidered the symbol of Judaism, For more details, Frankel E.,"Star of David", The Encyclopedia of Jewish Symbols, 1995,p.227

${ }^{25}$ http://cja.huji.ac.il/wpc/browser.php? mode=alone \&id=22504
} 


\subsection{In the Inner Hall}

On the walls of the inner halls, the palm motif is carved extensively:

\subsubsection{The Hall of Pahid Yitzhak Synagogue $e^{26}$}

On the lower section of the ceiling of the inner hall, a decoration of date palm with wreaths is carved in between the circular windows. The same motif is carved in the fence of the balcony of the women upper floor representing two intertwined date palm trees with David Star in the middle (PL.7 a-b). ${ }^{27}$

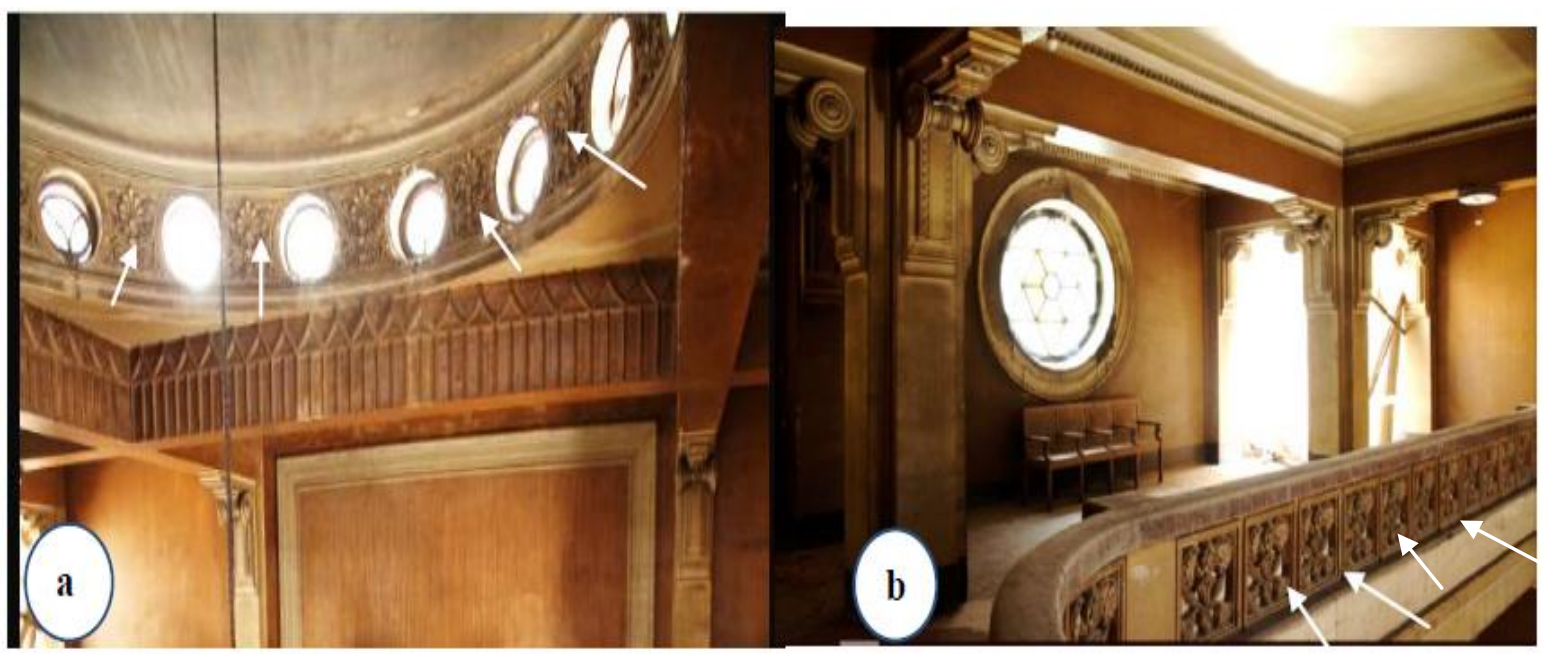

PL7. $a$ - The Date Palm Motif on the Lower Section of the Ceiling of the Inner Hall, $b$ - In the Fence of the Balcony

\subsubsection{The Hall of Etz Haim Synagogue $e^{28}$}

The date palm motif appeared decorating the lower frieze of the middle aisle alternating with the Law Tablets or Covenant Tablets and Star of David (PL.8).

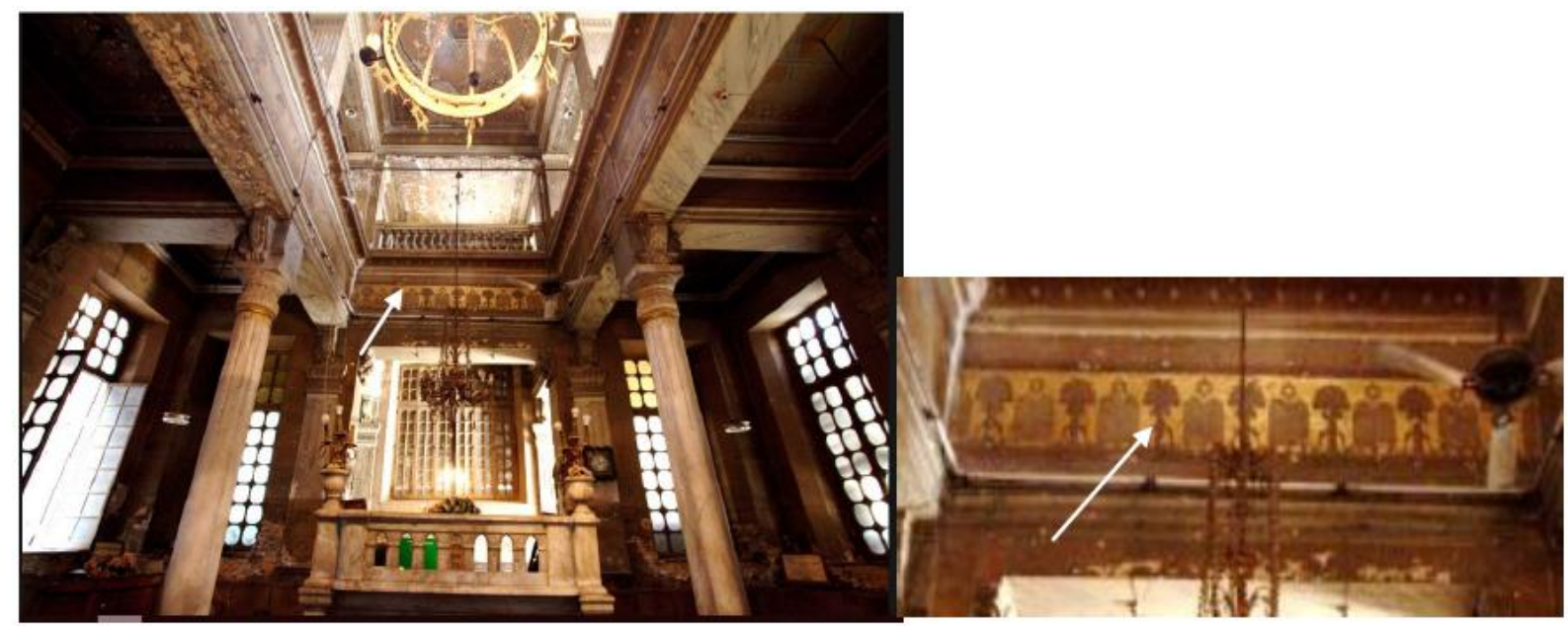

PL8. Left: The Date PalmMotif on the Lower frieze of the Middle Aisle, Right: A detailed section of the Frieze

\subsubsection{The Hall of Sha'ar Ha-Shamayim Synagogue}

The date palm motif with two wreaths alternating with David Star and Law Tablets can be seenin the register running under the stained glass windows in the upper part of the rear wall (PL.9). ${ }^{29}$

\footnotetext{
${ }^{26}$ Pahid Yitzhak synagogue is located in Abassiya, built in 1925 and also known as Kraim because of Mr.Zaki Kraim who oversaw the remodeling of it during his tenure as synagogue gabbai 1925-1932, https://diarna.org/exhibits/the-synagogues-of-cairo

${ }^{27}$ At first, the space set aside for the women was placed on the ground outside of the main mass of the structure, but as the available ground area became limited, especially in the cities, this space was moved to the upper stories, Tachau, W.G. The Architecture of the Synagogue,pp.168-169

${ }^{28}$ Etz Haim synagogue is also known as Hanan synagogue, located in Daher and dedicated in 1900,https://diarna.org/exhibits/the-synagogues-of-cairo
} 


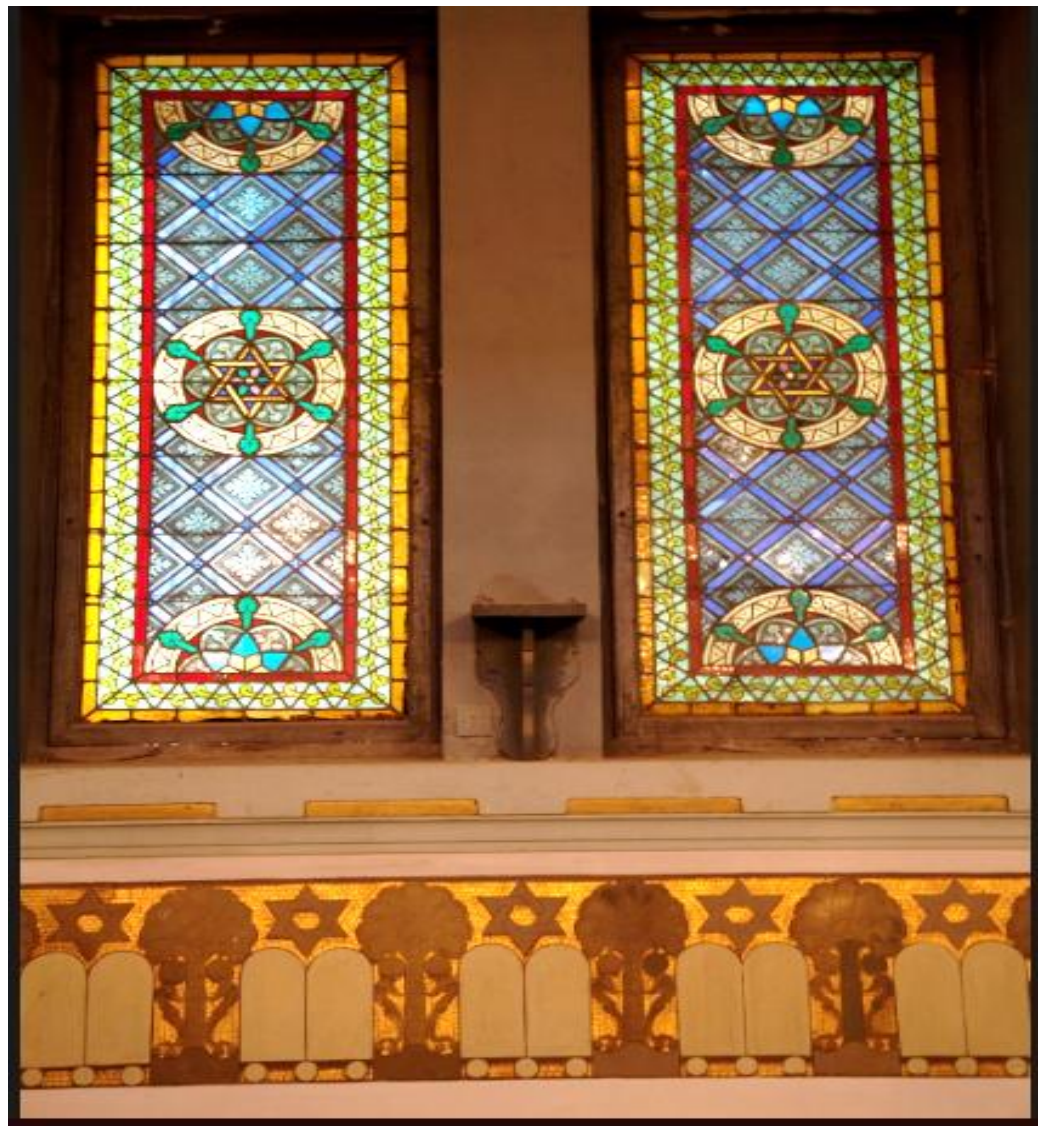

PL9. The Date Palm Motif alternating with David Star and Law Tablets

\subsection{Front and Side Doors}

\subsubsection{The Front Door of Meir Enayim Synagogue}

The double-leaf front door is decorated with beautiful engraved palm motif, but this time the artist concentrated only on the outlines of the date palm (PL.10).

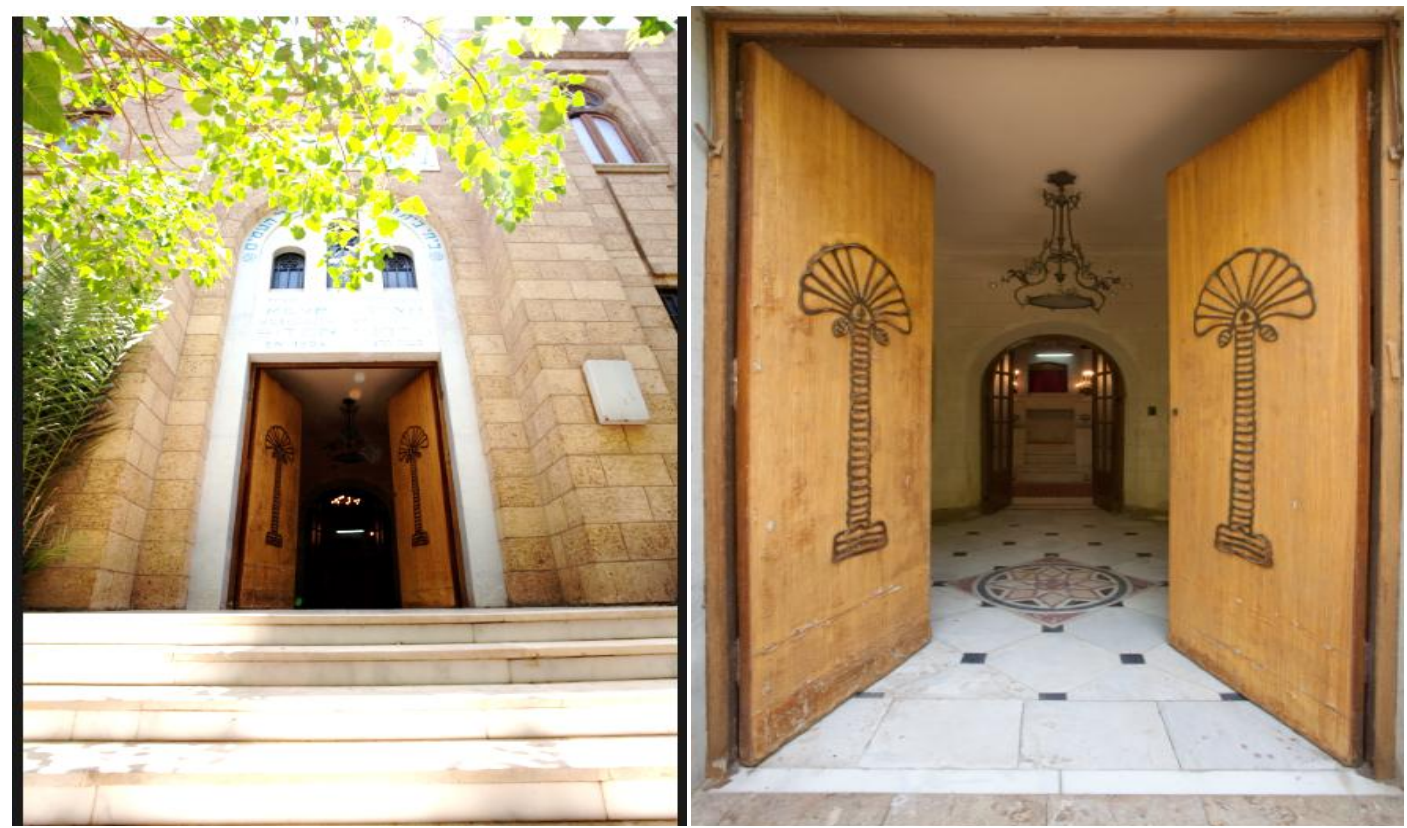

PL10. The Date Palm Motif on the Front Door

\footnotetext{
${ }^{29}$ The stained-glass windows in the sanctuary have pointed arches; these windows contain very beautiful geometric designs, including two yellow semicircles and one complete yellow circle within a blue and green patterned ornamental background, Kern-Ulmer R.,The Sha'ar Ha-Shamayim Synagogue (Keniset Ismā '̀llyah) in Cairo, p.438
} 


\subsubsection{The Front Door of Sha'ar Ha-Shamayim Synagogue}

Two date palms decorate the double-leaf front door of the synagogue, represented on the middle of a background of stained glass, the door fitting and also the key take the shape of palm tree (PL.11 $\mathbf{a , b}, \mathbf{c}, \mathbf{d}){ }^{30}$
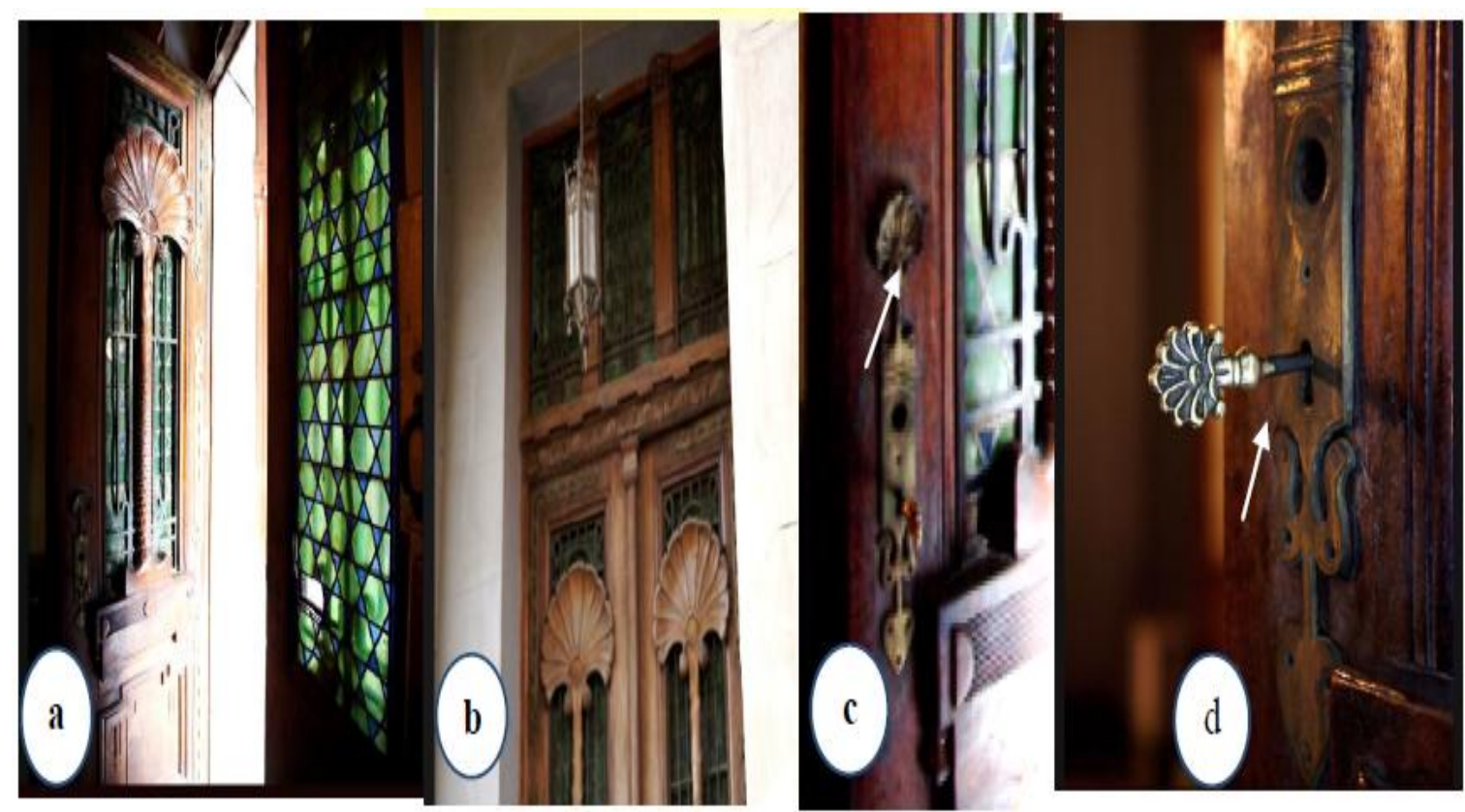

PL11. $a$-The Date Palm Motif on the Front Door, b-The Door From outside, $c$-The Door Fitting, $d$-The Door Key

\subsection{Facade}

The synagogue of Sha'ar Ha-Shamayim is the only one in Cairo to have the palm motif decoration on its front and side facades:

On the front façade are four eye-catching date palms engraved in the natural size in the area between the upper and lower windows. Each palm tree is in high relief; the stem is crowned by a circle of palm branches from which hang two clusters of dates. Two similar palms are sculptured beautifully on both sides of the side door, placed on two pedestals. ${ }^{31}$

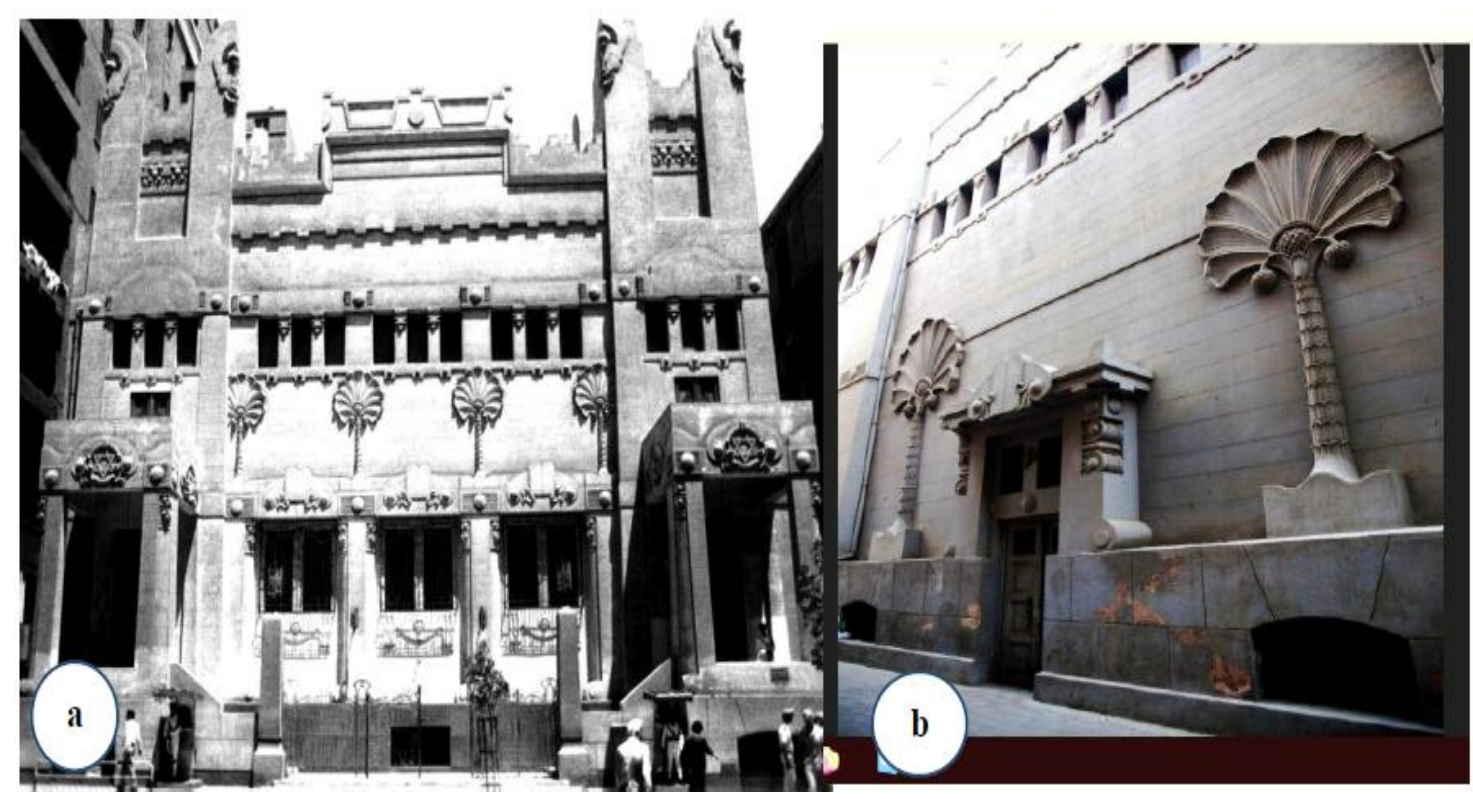

PL12. $a$-The Front Façade of the Synagogue, $b$-The Side Door flanked by two Date Palms

\footnotetext{
${ }^{30}$ https://diarna.org/exhibits/the-synagogues-of-cairo-and-alexandria-egypt-selected-sites

${ }^{31}$ Kern-Ulmer R., The Sha'ar Ha-Shamayim Synagogue (Keniset Ismā'ìlìyah) in Cairo, p.434
}

International Journal of History and Cultural Studies (IJHCS) 


\subsection{Furniture}

A wooden piece of furniture in the outer courtyard of Etz Haim synagogue, probably it was designed to conceal women's section as it is connected with another open area that maybe used by men, or it was a part of the sanctuary parts but was replaced by a new one, it bears a representation of six date palms executed in high relief with David Star above the first and last palm trees (PL.13).

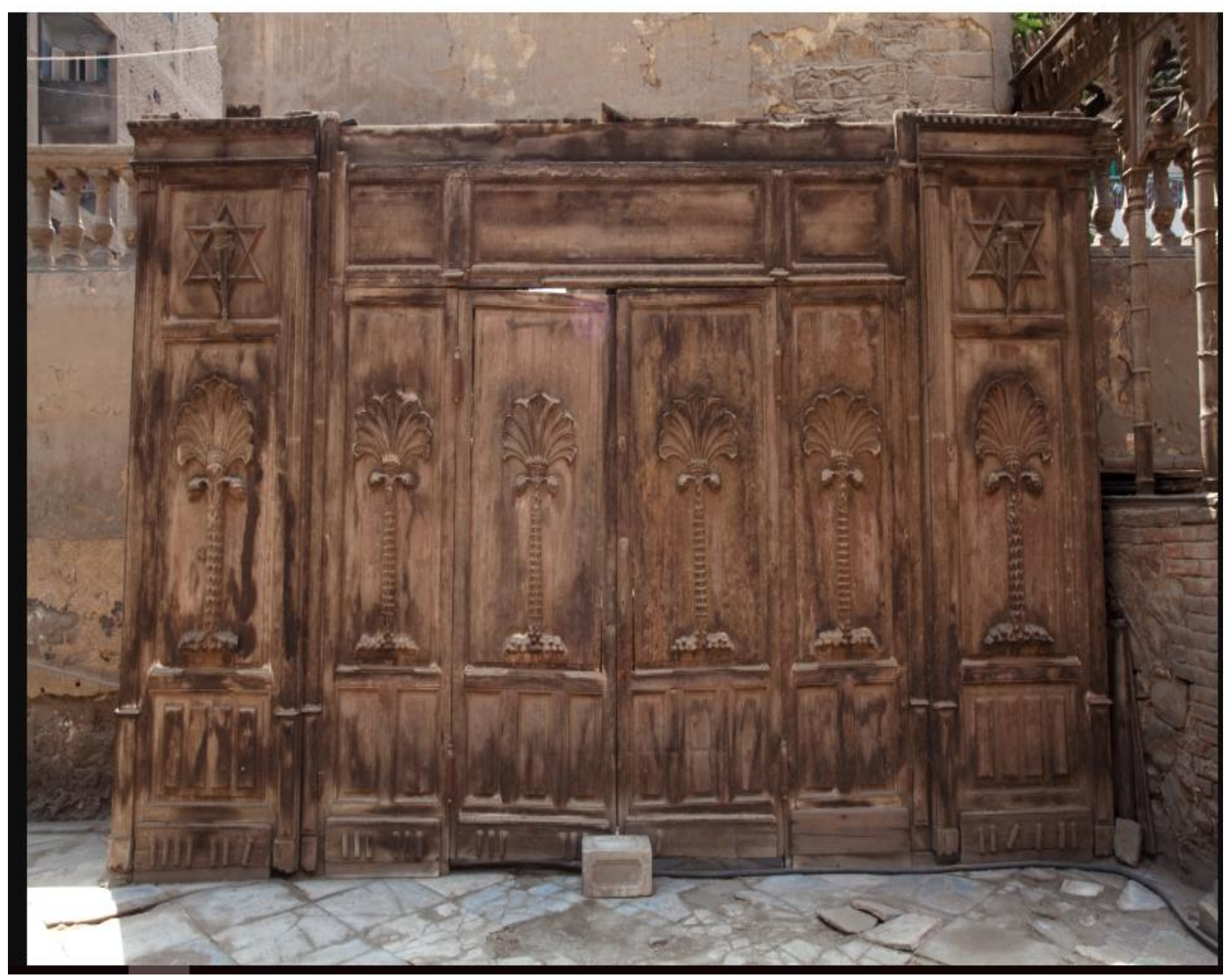

PL13. The Date Palm Motif on the Wooden Object of the Outer Courtyard

\section{Analytical Study}

As previewed, the date palm motif was used extensively in the decoration of the synagogues of Cairo; through (Table 1) the researcher summarized all these representations in different parts of the synagogue, it can be concluded that:

1- The date palm is a sacred symbole in Juidaism; therefore the artist was keen on representing it skillfully in detail in different part of the synagogue, in different materials, including stone, wood and metal, in different sizes and forms, alternating with other Jewish symbols like David Star and Law Tablets.

2- The sanctuary is the most sacred part in the synagogue as it houses the Ark and Torah scrolls, and this sacredness is confirmed by the several decorations of the date palm, then the courtyard and the other parts of the synagogue.

3- It is noteworthy that the reeds of the palm, which are considered the most distinguished part of the palm, adopt the odd numbers in its forms; seven, nine and eleven. According to Talmud, odd numbers are lucky, while even numbers are unlucky. ${ }^{32}$

As for number seven, it is a sacred number with great mystic power, mentioned many times in the Bible referring to the days of creation, the ancestors of Israel, the seven species, the seven chords of David's harp and the Torah portions as it is divided into seven sections.

${ }^{32}$ Frankel E.,"Seven”, The Encyclopedia of Jewish Symbols, 1995,p.121

International Journal of History and Cultural Studies (IJHCS) 
Number nine signifies finality, harvest, fruitfulness that is why the menorah has nine branches, while number eleven is mentioned in the story of Joseph's dream referring the eleven stars. ${ }^{33}$

4- Generally, the various representations of the date palm inside the synagogues in different sizes is definitely a way to convey some specific symbolic messages:-

- The palm tree grows slowly in a barren soil but steadily from century to century, uninfluenced as other trees either by the abundant rains of winter or the burning sun of summer, it is slender and very yielding, so that in a storm it sways back and forth, but does not break, therefore it signifies the strong personality of each Jew, no matter happens around him and no matter the difficulties of life facing him, he will continue and survive. ${ }^{34}$

- The date-palm relies for nourishment upon its roots, the emphasizing on representing the roots in detail, confirming that the synagogue represents the roots of any Jew, and without it he will die, therefore whenever he goes, he must be always connected to it, directed to God.

- Palm always provides man with food and shelter, announcing the availability of water in the barren desert, so does the synagogue which considers the refuge of the Jews where the souls can rest.

- The righteous Jew is exactly like the palm tree which gives its best fruit when it has reached a hundred years, like the righteous Jew who lives a good long life according to the Jewish instructions, directed toward the Holy One, he will be rewarded at his old age with the best fruits of his commitment: "They were there not only as ornaments, but as highly suggestive symbols of the reward of the righteous who, as a result of patience in well-doing, would have a flourishing old age". (Kings 1, vi, 29). ${ }^{35}$

- The palm tree has been described as "a friendly lighthouse that guide the traveler in his journey to the spot where water is to be found" (Ps. 92:13), exactly like the synagogue that guides the Jews through their life and unites all scattered Jews all over the world.

\section{CONCLUSION}

Cairo has enjoyed a rich history that extended for hundreds of years. The Jews lived in Cairo for many decades, practiced many notable activities, and left us many spectacular synagogues that are a witness to this prosperous period and a living example of Judaism in Egypt. The Jewish artist has used many symbolic motifs to ornament the synagogues, especially those mentioned in the Bible. Among these symbols is the date palm which appeared in several places inside the synagogues of Cairo, on façade, doors, walls and in the sanc6yytuary alternating with other Jewish symbols like David Star and Law Tablets. The artist skillfully used different materials like stone, wood and metal to highlight its significance. The date palm indicates the strong personality of the Jew and considers the symbol of the synagogue and its vital role in the life of the Jews.

To sum up, Judaism is a religion of symbols, and the synagogues of Cairo, which are decorated with many of them, offers a great opportunity for those who are interested in studying these symbols.

Table1. The Representations of the Date Palm in the Synagogues of Cairo

\begin{tabular}{|l|l|l|l|}
\hline $\begin{array}{l}\text { NAME OF } \\
\text { THE } \\
\text { SYNAGOGUE }\end{array}$ & WHERE & Description & MATERIAL/ PLATE \\
\hline $\begin{array}{l}\text { Moussa Dari / } \\
\text { Al Waili /1933 }\end{array}$ & Sanctuary & $\begin{array}{l}\text { Double reed on both sides of } \\
\text { the sanctuary }\end{array}$ & Stone, High relief/ PL.1A \\
\hline $\begin{array}{l}\text { Moussa Dari / } \\
\text { Al Waili/1933 }\end{array}$ & Ark Door & $\begin{array}{l}\text { Four Date palms on four } \\
\text { panels, 11 reeds, detailed } \\
\text { stem }\end{array}$ & $\begin{array}{l}\text { Wood, High relief } \\
\text { PL.1B }\end{array}$ \\
\hline $\begin{array}{l}\text { Haim Capousi } \\
\text { /Haret Ark }\end{array}$ & $\begin{array}{l}\text { A Double leaf door } \\
11 \text { reeds, detailed stem, }\end{array}$ & $\begin{array}{l}\text { Wood, High relief } \\
\text { PL.2 }\end{array}$ \\
\hline
\end{tabular}

\footnotetext{
${ }^{33}$ Levias c.,"NUMBERS AND NUMERALS", Jewish Encyclopedia, V.9, P.349

${ }^{34}$ Farbridge M.H., Studies in Biblical and Semitic Symbolism,P.40

${ }^{35}$ Kern-Ulmer R.,The Sha'ar Ha-Shamayim Synagogue (Keniset Ismà'ìlìyah) in Cairo,P.433; Farbridge M.H.,Studies in Biblical and Semitic Symbolism,P.41
} 


\begin{tabular}{|c|c|c|c|}
\hline Yahoud/1631 & & $\begin{array}{l}\text { Tablets of Law in the } \\
\text { middle of each stem with } \\
\text { Hebrew inscriptions }\end{array}$ & \\
\hline $\begin{array}{l}\text { Pahad Yitzhak } \\
\text { (Kraim)/ } \\
\text { Abassiya/ } 1925\end{array}$ & $\begin{array}{l}\text { Inner Hall, lower section of } \\
\text { the ceiling, palm decoration } \\
\text { in between the circular } \\
\text { windows. } \\
\text { In the fence of the upper } \\
\text { floor balcony }\end{array}$ & $\begin{array}{l}\text { Interlacing with wreaths, } 11 \\
\text { reeds } \\
\text { Two intertwined date palms } \\
\text { with David Star in the } \\
\text { middle }\end{array}$ & $\begin{array}{l}\text { Stone/ High relief } \\
\text { PL.7A } \\
\text { Stone/ High relief } \\
\text { PL.7B }\end{array}$ \\
\hline $\begin{array}{l}\text { Meir Enayim or } \\
\text { Meyr Biton / } \\
\text { Maadi /1934 }\end{array}$ & $\begin{array}{l}\text { Both sides of the Ark door } \\
\text { A double-leaf front door }\end{array}$ & $\begin{array}{l}\text { Two candelabras / } 7 \text { reeds, } \\
\text { equipped with the } 6 \text { lamps } \\
\text { each } \\
\text { High relief, only outlines, } \\
11 \text { reeds }\end{array}$ & $\begin{array}{l}\text { Wood/ Metal } \\
\text { PL.3 } \\
\text { Wood / High Relief } \\
\text { PL.10 }\end{array}$ \\
\hline $\begin{array}{l}\text { Etz Haim or } \\
\text { Hanan/ Daher/ } \\
1900\end{array}$ & $\begin{array}{l}\text { The lower friezeof the } \\
\text { middle aisle } \\
\text { Courtyard Furniture }\end{array}$ & $\begin{array}{l}11 \text { reeds alternating with } \\
\text { Law Tablets and Star of } \\
\text { David } \\
\text { Wooden piece consists of } 6 \\
\text { panels with palm motif } \\
9 \text { reeds, detailed stem }\end{array}$ & $\begin{array}{l}\text { Stone/ High relief } \\
\text { PL.8 } \\
\text { Wood/ High relief } \\
\text { PL.13 }\end{array}$ \\
\hline $\begin{array}{l}\text { Shaar } \\
\text { Hashamayim or } \\
\text { Ismailia } \\
\text { Temple / Adley } \\
\text { Street/ } 1899\end{array}$ & $\begin{array}{l}\text { Ark door } \\
\text { Sanctuary } \\
\text { Sanctuary } \\
\text { Sanctuary }\end{array}$ & $\begin{array}{l}4 \text { palm dates, } 11 \text { reeds, } \\
\text { detailed stem, in the area } \\
\text { between the upper and } \\
\text { lower windows } \\
\text { A Double leaf door ,11 } \\
\text { reeds, detailed body with } \\
\text { roots } \\
\text { Big Metal Candelabrum } \\
\text { with } 9 \text { reeds, detailed body, } \\
\text { many lamps, vegetal motifs } \\
\text { in the bottom, stands on } \\
\text { wooden pedestal. } \\
\text { Two large palm tree } \\
\text { Candelabras, placed on } \\
\text { marble columns, } 7 \text { reeds } \\
\text { with } 6 \text { lamps } \\
\text { On the rear wall of the } \\
\text { sanctuary alternating with } \\
\text { Law Tablets and David Star, } \\
9 \text { reeds } \\
2 \text { palm dates on the double- } \\
\text { leaf front door with the } \\
\text { stained-glass } \\
\text { background, } 11 \text { reeds, } \\
\text { detailed stem } \\
\text { The same front door has } \\
\text { fitting in a form of a palm } \\
\text { date and also a key } \\
\text { Two palms with } 9 \text { reeds } \\
\text { represented on both sides of } \\
\text { the side door, placed on } \\
\text { pedestals }\end{array}$ & $\begin{array}{l}\text { Wood and Metal } \\
\text { PL.4B } \\
\text { Stone/High relief } \\
\text { PL.5B } \\
\text { Wood/stained glass/ High } \\
\text { relief, PL.11A,11B } \\
\text { Metal objects } \\
\text { PL.11C,11D } \\
\text { Stone/ high relief } \\
\text { PL.12B }\end{array}$ \\
\hline
\end{tabular}




\begin{tabular}{|c|c|c|c|}
\hline & $\begin{array}{l}\text { Inner Hall } \\
\text { Ark }\end{array}$ & $\begin{array}{l}\text { Decoration on the wall } \\
\text { under the stained-glass } \\
\text { windows alternating with } \\
\text { David Star and Law Tablets } \\
\text { Wooden carvings of date } \\
\text { palm on both sides of the } \\
\text { Ark }\end{array}$ & $\begin{array}{l}\text { Stone/High relief } \\
\text { PL.9 } \\
\\
\text { Wood } \\
\text { PL.4A }\end{array}$ \\
\hline $\begin{array}{lr}\text { Maimoides } & / \\
\text { Haret } & \text { El } \\
\text { Yahoud } & \end{array}$ & Torah Case & $\begin{array}{l}13 \text { reeds palm with two } \\
\text { clusters of dates is set in the } \\
\text { center, topped by the } \\
\text { Tablets of the Covenant } \\
\text { inscribed with the Ten } \\
\text { Commandments }\end{array}$ & $\begin{array}{l}\text { Wood/Silver } \\
\text { PL.6 }\end{array}$ \\
\hline
\end{tabular}

\section{REFERENCES}

[1] Morabia A., “L'etoile et la Croissant”, in Juifs D'Egypt, Images et Textes, edited by Cabasso, G.,Carasso E., and Cohen A., 1984, pp.27-28

[2] Miccoli, D., Histories of the Jews of Egypt: An Imagined Burgeoisie”, 1880s-1950s. Routledge, 2015,pp.4-10

[3] Tachau, W.G. The Architecture of the Synagogue, Jewish Pub. Soc. of America, 1926,p.155

[4] Jacobs J., BrunnerA. W., "SYNAGOGUE ARCHITECTURE”, Jewish Encyclopedia.V.11, P.631-P.640

[5] Bacher W., Dembitz L.N., "SYNAGOGUE", Jewish Encyclopedia.V.11, P.619-

[6] Frankel E., Teutsch B.P.,” Lulav”, The Encyclopedia of Jewish Symbols, Oxford,1995, p.2016

[7] Hirsch E.G., Levi G.B.,’PALM (Phœnix dactylifera)",Jewish Encyclopedia, V.9,PP.505-506

[8] Farbridge M.H., Studies in Biblical and Semitic Symbolism, Trübner's Oriental Series, Routledge, 2000,p.39

[9] Kern-Ulmer R., "The Sha'ar Ha-Shamayim Synagogue (Keniset Ismā’̄ilìyah) in Cairo, Egypt”,PP.432,in Maven in Blue Jeans, A Festschrift in honor of Zev Garber, edited by Steven Leonard Jacobs, Purdue University Press, 2009

[10] Frankel E., "Four Species", The Encyclopedia of Jewish Symbols, Oxford,1995,p.59

[11] Jastrow M., Jr., McCurdy J.F., and others,” ARK OF NOAH”, Jewish Encyclopedia, V.2, P.P.111

[12] Taragan H., The "Gate of Heaven"(Sha'ar Hashamayim) Synagogue in Cairo (1898-1905): On the Contextualization of Jewish Communal Architecture, Journal of Jewish Identities 2009, 2(1),PP.31-53

[13] Hirsch E.G., "Tables of the Law", Jewish Encyclopedia, V.11,P.662

[14] Frankel E., "Star of David", The Encyclopedia of Jewish Symbols, 1995,p.227

[15] Frankel E., "Seven", The Encyclopedia of Jewish Symbols, 1995,p.121

[16] Levias c., "NUMBERS AND NUMERALS", Jewish Encyclopedia, V.9, P.349

\section{WEBSITES}

https://diarna.org/exhibits/the-synagogues-of-cairo-and-alexandria-egypt-selected-sites, copyright 2015 Digital Heritage Mapping

http://cja.huji.ac.il/wpc/browser.php?mode=alone\&id=22504

http://www.jewishencyclopedia.com/articles/11619-

Citation: Manal Mahmoud Abdelhamid. "The Significance of the Date Palm as a Decorative Motif in the Synagogues of Cairo, Egypt" International Journal of History and Cultural Studies (IJHCS). vol 6, no. 1, 2020, pp. 01-13. doi: DOI: http://dx.doi.org/ 10.20431/2454-7654.0601003.

Copyright: (C) 2020 Authors. This is an open-access article distributed under the terms of the Creative Commons Attribution License, which permits unrestricted use, distribution, and reproduction in any medium, provided the original author and source are credited. 